\title{
Thermal Pretreatment of Wood for Co-gasification/co-firing of Biomass and Coal
}

\author{
$\underline{\text { Ping Wang. }}{ }^{1}$, Bret Howard ${ }^{1}$, Sheila Hedges ${ }^{1}$, Bryan Morreale ${ }^{1}$, Dirk Van Essendelft ${ }^{2}$ and David \\ Berry $^{2}$ \\ 'NETL, 626 Cochrans Mill Road, Pittsburgh, PA 15236, USA ping.wang@netl.doe.gov \\ ${ }^{2}$ NETL, 3610 Collins Ferry Road, Morgantown, WV, 26507, USA
}

\begin{abstract}
Utilization of biomass as a co-feed in coal and biomass co-firing and co-gasification requires size reduction of the biomass. Reducing biomass to below $0.2 \mathrm{~mm}$ without pretreatment is difficult and costly because biomass is fibrous and compressible. Torrefaction is a promising thermal pretreatment process and has the advantages of increasing energy density, improving grindability, producing fuels with more homogenous compositions and hydrophobic behavior. Temperature is the most important factor for the torrefaction process. Biomass grindability is related to cell wall structure, thickness and composition. Thermal treatment such as torrefaction can cause chemical changes that significantly affect the strength of biomass. The objectives of this study are to understand the mechanism by which torrefaction improves the grindability of biomass and discuss suitable temperatures for thermal pretreatment for co-gasification/cofiring of biomass and coal. Wild cherry wood was selected as the model for this study. Samples were prepared by sawing a single tangential section from the heartwood and cutting it into eleven pieces. The samples were consecutively heated at $220,260,300,350,450$ and $550^{\circ} \mathrm{C}$ for $0.5 \mathrm{hr}$ under flowing nitrogen in a tube furnace. Untreated and treated samples were characterized for physical properties (color, dimensions and weight), microstructural changes by SEM, and cell wall composition changes and thermal behaviors by TGA and DSC. The morphology of the wood remained intact through the treatment range but the cell walls were thinner. Thermal treatments were observed to decompose the cell wall components. Hemicellulose decomposed over the range of $\sim 200$ to $300^{\circ} \mathrm{C}$ and resulted in weakening of the cell walls and subsequently improved grindability. Furthermore, wood samples treated above $300^{\circ} \mathrm{C}$ lost more than $39 \%$ in mass. Therefore, thermal pretreatment above the hemicelluloses decomposition temperature but below $300^{\circ} \mathrm{C}$ is probably sufficient to improve grindability and retain energy value.
\end{abstract}




\section{Introduction}

The U.S. has abundant coal and biomass resources. Biomass is a renewable and carbon-neutral energy source. Biomass/coal co-firing at existing power and co-gasification plants are innovative technologies for reducing $\mathrm{CO}_{2}$ emissions. Adding biomass to coal-based energy production processes could enable biomass to be utilized on a larger scale. However, utilization of biomass as a co-feed requires size reduction of the biomass. Reducing biomass to below $0.2 \mathrm{~mm}$ without pretreatment is difficult and costly because biomasses are fibrous and compressible [1] . Torrefaction is a promising thermal pretreatment process and has the advantages of increasing energy density, improving grindability, producing fuels with more homogenous compositions and hydrophobic behavior [2]. In torrefaction, biomass is treated at 200 to $300^{\circ} \mathrm{C}$ in the absence of oxygen near atmospheric pressure. During the process, biomass is partly decomposed generating various types of volatile compounds. The remaining solid is known as "torrefied biomass". After torrefaction, biomass becomes brittle and friable so its grindability is improved [3, 4]. For wood treated at $240^{\circ} \mathrm{C}$ for $0.5 \mathrm{hr}$ and ground, the percentage of particles less than $415 \mu \mathrm{m}$ and $150 \mu \mathrm{m}$ were double that of untreated wood [5]. Temperature is the most important factor for the torrefaction process. Biomass grindability is related to cell wall structure, thickness and composition [6,7]. Wood and wood residues are one of the major sources of biomass along with agricultural residues, energy crops, municipal solid wastes (MSW), and industrial wastes and co-products [8]. Wood is basically a series of tubular fibers or cells cemented together $[6,7]$. Each cell well is composed of various quantities of three polymers: cellulose, hemicelluloses, and lignin. Cellulose is primarily responsible for the strength of wood. Hemicellulose acts as a matrix for the cellulose and increases the packing density of the cell walls. Lignin holds wood fibers together. Thermal treatment such as torrefaction can cause chemical changes that significantly affect the strength of biomass. The objectives of this study are to understand the mechanism by which torrefaction improves the grindability of biomass and discuss suitable temperatures for thermal pretreatment for co-gasification/co-firing of biomass and coal.

\section{Materials and Experiments}

Cherry wood (American black), obtained locally in Pittsburgh, PA, was selected as a model for this study. The wood samples used in this study were prepared by the following method. First, a $16 \mathrm{~mm}$ thick slice of wood was cut across the grain (longitudinal cell); second, a $7 \mathrm{~mm}$ tangential section was cut from the heartwood in the slice; and, finally, eleven pieces having dimensions of about $16 \mathrm{~mm} \times 7 \mathrm{~mm} \times 5 \mathrm{~mm}$ (length, width, thickness) were obtained from the section. The purpose of taking the samples from a single tangential section in the heartwood was to limit the natural variability of the wood and improve the reproducibility of results.

In the sample treatment, the samples were consecutively treated at $220,260,300,350,450$ and $550^{\circ} \mathrm{C}$ for $0.5 \mathrm{hr}$ for each temperature under flowing nitrogen in a tube furnace. After each treatment, the samples were characterized. Untreated samples were used as a reference. Two samples were used to follow microstructural changes throughout the treatment by scanning electron microscope (SEM). Two samples were used to characterize physical property changes (colors, dimensions and weights). These four samples were taken through all the temperature treatments. The remaining seven samples were analyzed by thermogravimetric analyzer (TGA) (Perkin Elmer model Pyris 1 TGA) and by differential scanning calorimetry (DSC) (Perkin Elmer model Pyris Diamond DSC) to investigate cell wall composition changes and thermal behaviors. One sample was removed after each temperature treatment in the sequence; therefore, each sample at a given temperature was cumulatively exposed to all the thermal treatments at lower temperatures. For the SEM analyses, three plane sections (tangential, radial, and transverse) for each sample, and twelve spots for each section were examined using six magnifications for each spot resulting in a total of 216 images. In the TGA test, a non-isothermal method was used at a $2^{\circ} \mathrm{C} / \mathrm{min}$ heating rate from 25 to $800^{\circ} \mathrm{C}$ under nitrogen. Model compounds representing typical cell wall compositions were analyzed by TGA to aid in indentifying cell wall component changes in the treated wood samples. Cellulose (fibrous, long), xylan (used as a model of hemicelluloses) from birchwood and 
beechwood, and lignin (alkali) were selected as the model components. For DSC, the samples were tested at a $2^{\circ} \mathrm{C} / \mathrm{min}$ heating rate from 25 to $600^{\circ} \mathrm{C}$ under nitrogen.

\section{Results and Discussion}

Pliysical properties of untreated and treated woods. Table 1 shows the physical properties of untreated versus treated wood at $220,260,300,350,450$ and $550^{\circ} \mathrm{C}$. Thermal treatments were found to darken the wood samples, as expected. The samples were essentially black after the $260^{\circ} \mathrm{C}$ treatment. The dimensions of the wood were reduced in all directions and shrinkage increased as treatment temperature increased. The shrinkage along radial direction was more than in the axial direction. Losses of weight and volume increased as treatment temperature increased. At $350^{\circ} \mathrm{C}$, the weight loss $(62.07 \%)$ and volume loss $(37.39 \%)$ were much higher than the weight loss $(39.21 \%)$ and volume loss $(15.11 \%)$ at $300^{\circ} \mathrm{C}$. The densities of the wood samples decreased with increasing temperature over the temperature range of 220 to $300^{\circ} \mathrm{C}$ but changed little over the range of 350 to $550^{\circ} \mathrm{C}$.

Table 1. Physical property changes of untreated and treated woods at each treatment temperature

\begin{tabular}{|l|r|r|r|r|r|r|r|r|}
\hline Treated temp ( $\left.{ }^{\mathbf{0}} \mathbf{C}\right)$ & $\mathbf{2 5}$ & $\mathbf{2 2 0}$ & $\mathbf{2 6 0}$ & $\mathbf{3 0 0}$ & $\mathbf{3 5 0}$ & $\mathbf{4 5 0}$ & $\mathbf{5 5 0}$ \\
\cline { 2 - 8 } $\begin{array}{r}\text { Color } \\
\text { Weight loss (\%) }\end{array}$ & 0 & 15.84 & 27.57 & 39.21 & 62.07 & 69.70 & 73.22 \\
\hline Long shrinkage (\%) & 0 & 0.09 & 0.06 & 0.41 & 6.48 & 12.51 & 15.34 \\
\hline Widle shrinkage (\%) & 0 & 3.85 & 6.64 & 10.72 & 22.54 & 26.95 & 29.53 \\
\hline High shrinkage (\%) & 0 & 1.06 & 2.31 & 4.52 & 13.57 & 19.44 & 22.24 \\
\hline Volume loss (\%) & 0 & 4.96 & 8.85 & 15.11 & 37.39 & 48.52 & 53.60 \\
\hline Density (g/cm) & 0.54 & 0.48 & 0.43 & 0.39 & 0.33 & 0.32 & 0.31 \\
\hline Density change (\%) & 0 & -11.44 & -20.54 & -28.39 & -39.43 & -41.16 & -42.29 \\
\hline
\end{tabular}

Morphological study of untreated and treated woods by SEM. Figure 1 shows the SEM images (horizontal field width $=1.28 \mathrm{~mm}$; vertical as images are presented) of tangential section views of untreated and treated woods at 260 and $550^{\circ} \mathrm{C}$. The overall morphological features of the wood remain intact during wood shrinkage in both the radial and axial directions; however, there was more shrinkage

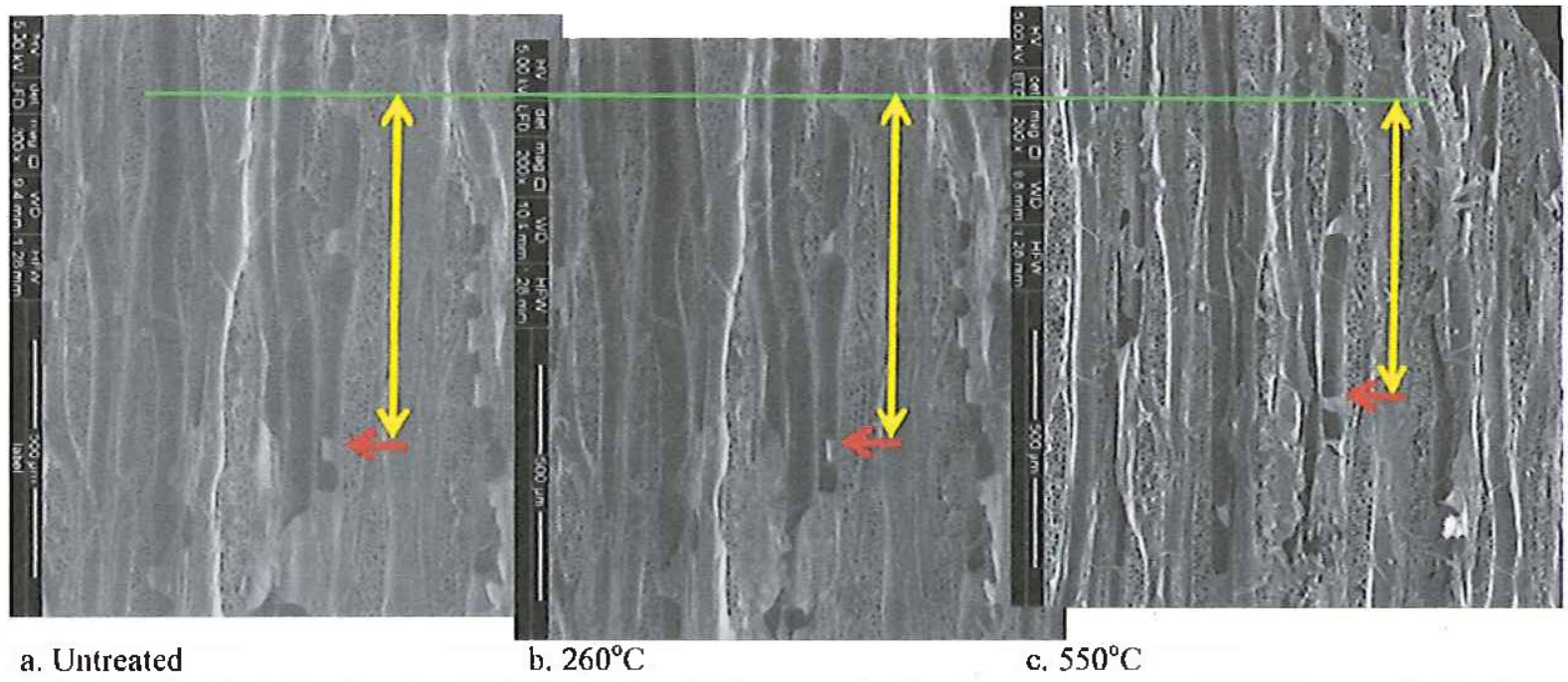

a. Untreated
Figure 1. SEM images (horizonal field width $=1.28 \mathrm{~mm}$; vertical as images are presented) of tangential section views of untreated and treated cherry wood samples. 


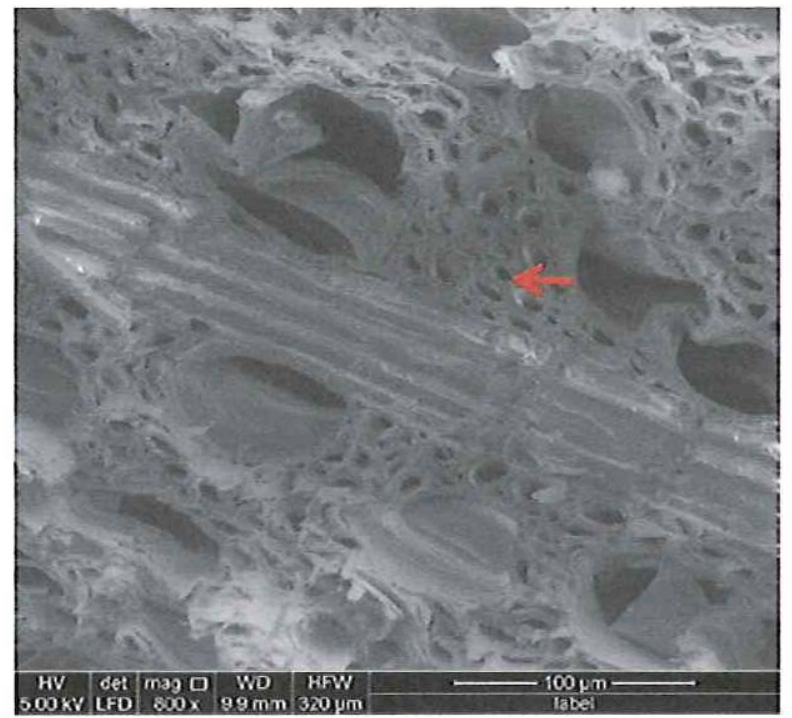

a. Untreated

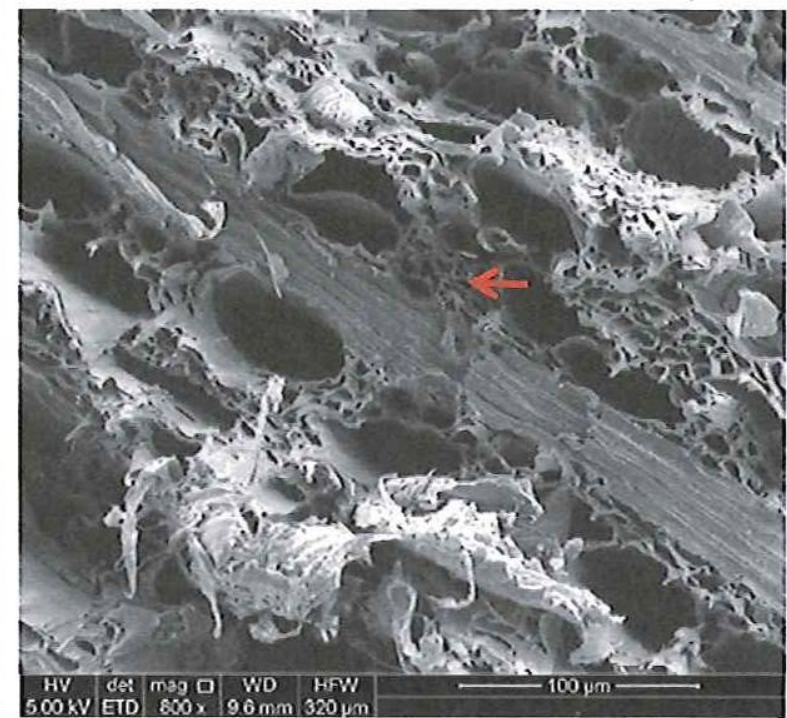

b. $550^{\circ} \mathrm{C}$

Figure 2. SEM images (horizontal field width $=320 \mu \mathrm{m})$ of transverse section views of untreated and treated cherry wood samples.

along the radial direction than the axial one. Figure 2 shows the SEM images (horizontal field width $=$ $320 \mu \mathrm{m}$ ) of transverse sections of untreated and treated woods at $550^{\circ} \mathrm{C}$. The cell walls were thinner after thermal treatments.

Cell wall component decomposition study of untreated and treated woods by TGA and DSC. Figure 3 shows the differential thermogravimetry (DTG) curves vs. temperature for long and medium cellulose fibers, xylans from beech and birch wood (representing hemicelluloses) and lignin (alkali). The DTG curves show a distinct primary peak for each model component. Xylan from birchwood and xylan from beechwood mainly decomposed over the range of about 200 to $300^{\circ} \mathrm{C}$ with peak maximums of $269^{\circ} \mathrm{C}$ and $274^{\circ} \mathrm{C}$, respectively. The long and medium cellulose fibers mainly decomposed over the range of about

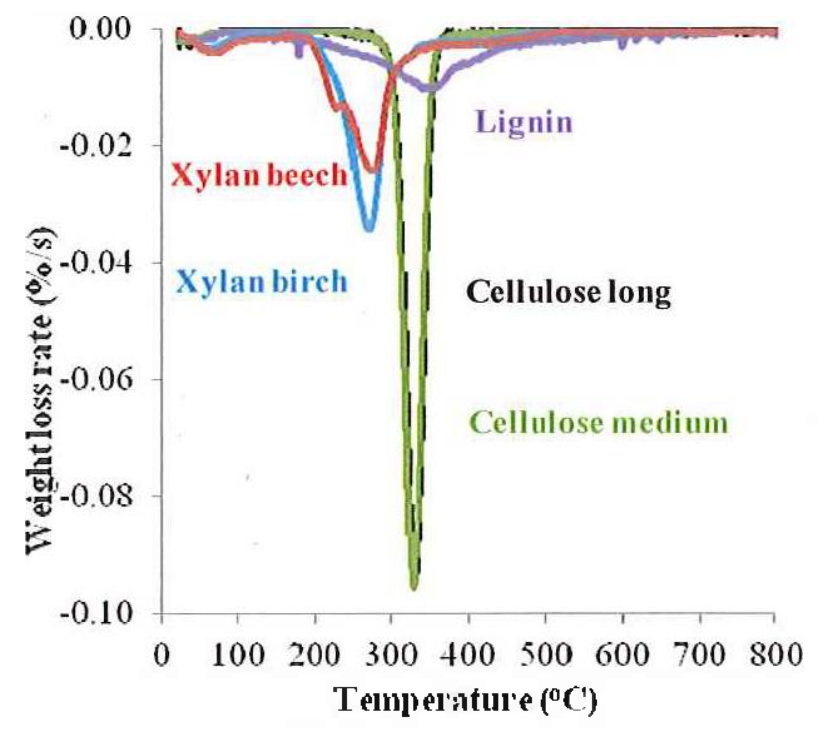

Figure 3. Differential thermogravimetry (DTG) curves us temperature for the pure model components (xylan/hemicelluloses, cellulose, and lignin) of biomass cell wall components. 
300 to $360^{\circ} \mathrm{C}$ with peak maximums of $330^{\circ} \mathrm{C}$ and $328^{\circ} \mathrm{C}$, respectively. Lignin slowly decomposed over the range of about 200 to $500^{\circ} \mathrm{C}$ with a peak maximum of $353^{\circ} \mathrm{C}$. The peak maximums of celluloses measured by both TGA and DSC were comparable (data not shown). The peak maximums observed for the xylans and lignin by TGA were slightly lower than those measured by DSC but still fell in a similar decomposition temperature ranges. All decompositions of celluloses, xylans, and lignin were endothermic in temperature range up to $600^{\circ} \mathrm{C}$. The order of energy required from high to low were cellulose, xylan and lignin.

Figure 4 show DTG curves vs. temperature for the untreated and treated woods at 220, 260, 300, 350, 450 and $550^{\circ} \mathrm{C}$. The DTG curve of the untreated wood showed a shoulder and a primary peak. Compared to the DTG curve of the model biomass cell wall components, the shoulder is likely due to the decomposition of hemicelluloses present in the wood. The primary peak is likely due to the decomposition of cellulose. The DTG curve of the $220^{\circ} \mathrm{C}$ treated wood was similar to the untreated wood but the weight loss rates were lower than those observed for the untreated sample over the 200 to $280^{\circ} \mathrm{C}$ range. This suggests that some hemicelluloses in the wood were decomposed during the thermal treatment at $220^{\circ} \mathrm{C}$. The treated woods at $260,300,350,450$ and $550^{\circ} \mathrm{C}$ had only one peak in their DTG curves. This indicates that the hemicelluloses in the samples were decomposed essentially completely during these thermal treatments. The DTG decomposition peaks of the 350,450 and $550^{\circ} \mathrm{C}$ treated woods were in the lignin composition range. This suggests that the cellulose in the samples was essentially all decomposed at those thermal treatment temperatures. These results compared well with the DSC results (not shown). During DSC tests, the amount of energy absorbed (heat of decomposition) for treated samples at 350,450 and $550^{\circ} \mathrm{C}$ was much less than observed for the lower temperature treated woods at 220,260 and $300^{\circ} \mathrm{C}$ since cellulose has the highest heat of decomposition of all the cell wall components of biomass. The DTG and DSC results show that thermal treatments decompose the cell wall components. Lignin and hemicellulose are the structural matrix for cellulose, therefore, as they are decomposed by the thermal treatment, the cell walls weaken and grindability subsequently improves. Cellulose itself decomposes in the range of 300 to $360^{\circ} \mathrm{C}$. Therefore, thermal pretreatment at a high enough temperature to decompose the hemicellulose but below $300^{\circ} \mathrm{C}$ is probably sufficient to improve grindability. Furthermore, wood treated at $300^{\circ} \mathrm{C}$ and higher lost more than $39 \%$ of its mass which results in a reduction of energy value (Table 1).

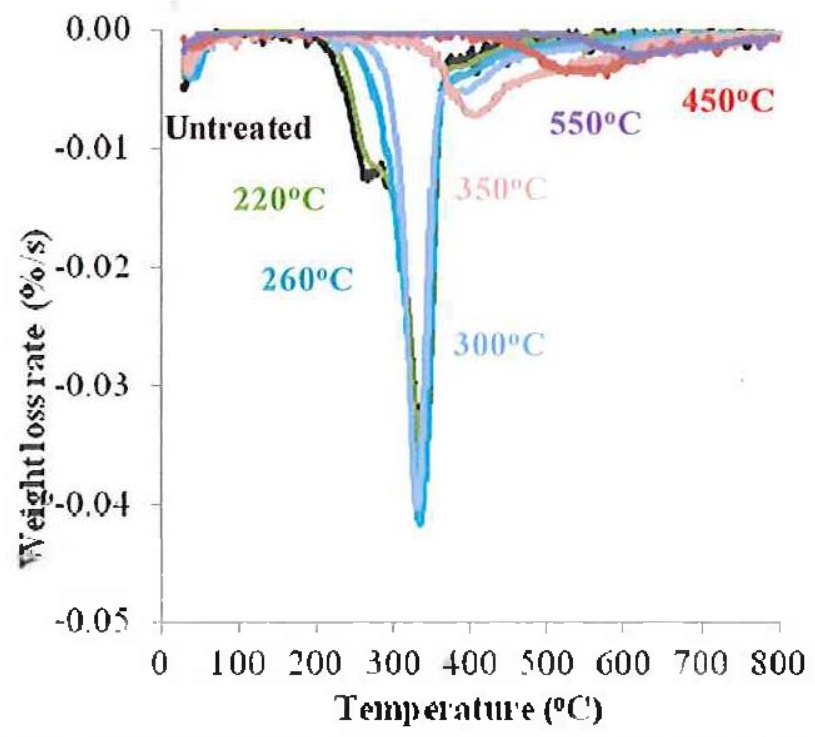

Figure 4. Differential thermogravimetry (DTG) curves vs temperature for untreated wood and woods treated at $220,260,300,350,450$ and $550^{\circ} \mathrm{C}$ for $0.5 \mathrm{hr}$. 


\section{Conclusions}

Samples of a model hardwood (cherry) were consecutively treated at $220,260,300,350,450$ and $550^{\circ} \mathrm{C}$ for $0.5 \mathrm{hr}$ at each temperature under nitrogen. The thermal treatments changed the physical properties, chemical compositions and microstructures of the wood. The wood samples darkened increasingly at each temperature and were essentially black after $260^{\circ} \mathrm{C}$. The dimensions of the wood were reduced in all directions and shrinkage increased with increased treatment temperature. The shrinkage along the radial direction was more than along the axial direction. Losșes of weight and volume increased with increased treatment temperature. The morphologies of the wood samples remained essentially intact over the treatment temperature range but the cell walls were observed to be thinner. Thermal treatments decompose the cell wall components of hemicelluloses $\left(\sim 200\right.$ to $\left.300^{\circ} \mathrm{C}\right)$, cellulose $\left(\sim 300\right.$ to $\left.360^{\circ} \mathrm{C}\right)$ and lignin $\left(200\right.$ to $\left.500^{\circ} \mathrm{C}\right)$. In the 260 and $300^{\circ} \mathrm{C}$ treated woods, hemicellulose was mostly decomposed but cellulose and lignin remained. Lignin and hemicelulose are the structural matrix for cellulose, therefore, as they are decomposed by the thermal treatment, the cell walls weaken and grindability subsequently improves. The wood samples treated at 350,450 and $550^{\circ} \mathrm{C}$ had more than a $39 \%$ mass loss. This results in a large reduction of energy value since both hemicelluloses and cellulose were decomposed. Therefore, thermal pretreatment at a high enough temperature to decompose the hemicellulose but below $300^{\circ} \mathrm{C}$ is probably sufficient to improve grindability.

\section{References}

[1] Bergman PCA, Kiel JHA. Torrefaction for biomass upgrading. 14th European Biomass Conference \& Exhibition. Paris, France, 2005.

[2] Bergman PCA, Boersma AR, Zwart RWR, Kiel JHA. Torrefaction for biomass co-firing in existing coal-fired power stations "Biocoal". ECN-C-05-013, 2005.

[3] Phanphanich M, Mani S. Impact of torrefaction on the grindability and fuel characteristics of forest biomass. Bioresource Technology 2011, 102, 1246-1253.

[4] Repellin V, Govin A, Rolland M, Guyonnet R. Energy requirement for fine grinding of torrefied wood. Biomass \& Bioenergy 2010, 34, 923-930.

[5] Arias B, Pevida C, Fermoso J, Plaza MG, Rubiera F, Pis JJ. Influence of torrefaction on the grindability and reactivity of woody biomass. Fuel Processing Technology 2008, 89, 169-175.

[6] Wiedenhoeft AC, Miller RB. Cell Wall Chemistry. In: Rowell RM, editor. Handbook of wood chemistry and wood composites. New York: Taylor \& Francis, 2005.

[7] Winandy JE, Rowell RM. Chemistry of wood strength. In: Rowell RM, editor. Handbook of wood chemistry and wood composites: New York: Taylor \& Friends, 2005.

[8] Wang P, Shuster E, Matuszewski M, Tarka T, VanEssendelft D, Berry D. Selection of biomass type for co-gasification studies. The 35th International Technical Conference on Clean coal \& fuel systems. Clearwater, FL, 2010. 